\title{
Teologia protestante das religiões: um horizonte teo-dialógico
}

\author{
Protestant theology of religions: \\ a theo-dialogical horizon
}

\section{Teología protestante de las religiones: un horizonte teo-dialógico}

\author{
Alonso Gonçalves* \\ Em memória de Alessandro Rodrigues Rocha (1973-2019), pastor, \\ pensador, provocador
}

\begin{abstract}
RESUMO
O artigo tem como objetivo contribuir com o debate em torno do tema da Teologia das Religiões, mas a partir da perspectiva protestante. Esse intento se justifica porque ainda há uma ausência de produção teológica em torno do tema a partir de teólogos e teólogas na América Latina. Nesse texto, destacamos a contribuição de dois teólogos latino-americanos para a temática da Teologia das Religiões, Claudio de Oliveira Ribeiro e Alessandro Rodrigues Rocha. Cada um, à sua maneira, nos fornece elementos para se pensar uma Teologia das Religiões em que a principal premissa é a pluralidade.

Palavras-chave: Teologia das Religiões; protestantismo; América Latina; pluralidade.
\end{abstract}

\begin{abstract}
The article aims to contribute to the debate around the theme of Theology of Religions, but from the Protestant perspective. This intention is justified because there is still a lack of theological production around the theme from theologians and theologians in Latin America. In this text, we highlight the contribution of two Latin American theologians to the theology of religions, Claudio de Oliveira Ribeiro and Alessandro Rodrigues Rocha. Each, in its own way, provides us with elements to think about a Theology of Religions in which the main premise is plurality.

Keywords: Theology of Religions; Protestantism; Latin America; plurality.

\section{RESUMEN}

El artículo tiene como objetivo contribuir al debate en torno al tema de Teología de las religiones, pero desde la perspectiva protestante. Esta intención está justificada porque todavía hay una falta de producción teológica en torno al tema por parte de teólogos y teólogos en América Latina. En este texto, destacamos la contribución de dos teólogos latinoamericanos a la teología de las religiones, Claudio de Oliveira Ribeiro y Alessandro Rodrigues Rocha. Cada uno, a su manera, nos proporciona elementos para pensar sobre una Teología de las Religiones en la cual la premisa principal es la pluralidad.

Palabras clave: Teología de las Religiones; protestantismo; América Latina; pluralidad.

Mestre e doutorando em Ciências da Religião na Universidade Metodista de São Paulo (Umesp). Bolsista FAPESP (Fundação de Amparo à Pesquisa do Estado de São Paulo - Processo n. ${ }^{\circ}$ 2017/09589-8), pesquisando Teologia das Religiões e Diálogo Inter-religioso a partir da Teologia Protestante. Contato: alonso3134@hotmail.com

** Alessandro Rodrigues Rocha. Doutor em Teologia (PUC-Rio); Pastor batista. Faleceu no dia 26 de Janeiro de 2019 aos 45 anos de idade.
\end{abstract}




\section{Introdução}

O pluralismo religioso se tornou uma problemática para a reflexão teológica na contemporaneidade. Na América Latina, mais especificamente, a discussão sobre o tema é frequente e a produção teológica é crescente. No campo católico, por exemplo, esse tema vem sendo articulado já há algum tempo, oferecendo uma contribuição importante. Por outro lado, o protestantismo latino-americano até o presente momento tem tido dificuldades em refletir teologicamente sobre o tema das religiões, sobretudo por razões históricas, quando de sua inserção no continente. ${ }^{1}$ É fato que, dentre as diferentes ramificações dos protestantismos na América Latina, podemos destacar a ala que ficou conhecida como sendo ecumênico-progressista. ${ }^{2}$ No entanto, esse segmento se ocupou dos temas ecumênicos, especialmente no tocante às questões práticas e pastorais, e não tanto do diálogo teológico com outras expressões religiosas. A preocupação se deu em dirimir o escândalo das divisões entre as igrejas e a distância com a Igreja Católica. Trabalho legítimo. Ocorre que, com isso, o debate em torno de outras expressões religiosas ficou deficitário, na verdade quase ausente, por razões específicas de um momento singular na América Latina. Não sem razão, há uma ausência de estudos sobre isso, ou seja, reflexões teológicas no campo protestante que dialoguem com as demais expressões religiosas, propondo uma teologia protestante latino-americana das religiões, contribuindo assim para um maior espaço teológico onde o diálogo inter-religioso seja valorizado a partir da perspectiva protestante.

1 "Infelizmente, o protestantismo na América Latina herdou pouco do debate da tradição protestante sobre a religião. Por aqui, o protestantismo é predominantemente herdeiro de uma concepção de mundo dividido em duas partes: de um lado, o mundo ocidental e cristão; de outro, o mundo oriental, pagão e objeto de missão" (WIRTH, 2006, p. 94).

2 Por "protestantismo ecumênico-progressista" entendemos fazer parte um pequeno segmento do protestantismo latino-americano que buscou enfrentar duas situações, uma interna e outra externa, em um contexto histórico específico. Assim resume Zwínglio M. Dias: "Os esforços pela unidade dos cristãos surgiram no e a partir do seio das igrejas evangélicas latino-americanas, obedecendo a uma dupla motivação: a primeira, de caráter interno, inter-eclesiástica e intra-sistêmica, dado que sua visão da sociedade latino-americana correspondia a uma percepção ingênua e acrítica da problemática social por parte de seus proponentes; a segunda, de caráter externo, nascida da visão sociopolítica de cristãos que viam urgência na necessidade de buscar soluções para os cadentes problemas da sociedade latino-americana, intentava sensibilizar a igreja em relação aos problemas que afligiam essa sociedade em termos estruturais. Gradualmente, esta tendência ecumênica foi demonstrando sua natureza anti-sistêmica e anti-institucional" (apud LONGUINI, 2002, p. 41). 
O que temos constatado é que há dificuldades para se ter teologias a partir da tradição protestante que contemplem o pluralismo religioso. Quando o assunto pluralismo religioso é tratado, em geral, é visto como um desafio ao movimento ecumênico. ${ }^{3}$ É sabido que há segmentos teológicos dentro do protestantismo que não se sentem provocados por essa questão, com isso não entendem que precisam dialogar ou pensar teologicamente sobre o tema das religiões. Por outro lado, o segmento ecumênico-progressista, que, em tese, poderia contribuir com a temática, não o fez até o presente momento de forma satisfatória e sistemática. Ainda assim, há autores que vêm contribuindo com a temática a partir da realidade latino-americana, propondo uma teologia das religiões em diálogo com o pluralismo religioso. Esse trabalho, em comparação com os autores do campo católico, ainda é incipiente, mas de muita qualidade. Diante disso, o presente texto tem como objetivo articular alguns elementos teológicos de autores latino-americanos, mais detidamente brasileiros, que contribuam para a temática da "Teologia das Religiões" a partir da perspectiva protestante. Por isso, chamamos de horizonte teo-dialógico: por se tratar de aberturas para o acolhimento de expressões religiosas, sem a pretensão de absolutidade do cristianismo ocidentalizado.

\section{Protestantismo latino-americano: do movimento ecumênico à teologia das religiões}

Quando o protestantismo latino-americano, de segmento progressista, estava fincando as estacas do movimento ecumênico, a preocupação era tratar o divisionismo das igrejas protestantes, focando, principalmente, em um trabalho comum diante das dificuldades socioeconômicas evidentes de um continente que sempre resistiu, em diferentes épocas, ao aprofundamento das suas mazelas. Mesmo assim, quando Júlio de Santa Ana escreveu Ecumenismo e libertação (1987), o teólogo de tradição metodista elaborou as bases para o ecumenismo na América Latina, demonstrando a amplitude do que seja o ecumênico, desde a percepção grega, teológico-bíblica até os

\footnotetext{
3 Estamos nos referindo a dois textos de teólogos de expressão na América Latina que, quando tratam do tema pluralismo religioso, vinculam-no, de maneira quase automática, à temática ecumênica: ALTMANN, Walter. "O pluralismo religioso como desafio ao ecumenismo na América Latina”. In: SUSIN, Luiz Carlos (Org.). Sarça ardente: teologia na América Latina - prospectivas. São Paulo: Paulinas/SOTER, 2000, p. 391-414; BITTENCOURT FILHO, José. "Pluralismo religioso: um desafio ao ecumenismo". In: KOINONIA (Org.). O sonho ecumênico: prefácio ao novo milênio. Rio de Janeiro: KOINONIA, 1995, p. 45-47.
} 
desafios das igrejas. Ainda que o movimento ecumênico estivesse focado em seus projetos de unidade e temas comuns entre igrejas, o autor se dá conta de que seria preciso, mais à frente, formular uma teologia ecumênica das religiões: "Entretanto, coexistem com as igrejas outras comunidades religiosas que dão testemunho de formas de experiência de Deus e do sagrado em termos diferentes das do cristianismo" (SANTA ANA, 1987, p. 11). Ainda que o autor não trate de outras religiões no seu texto que marcou uma geração de teólogos e teólogas protestantes na América Latina, ele admite que era preciso olhar para a diversidade de povos e a pluralidade religiosa latino-americana. Por isso ele nomeia as "outras comunidades religiosas", dizendo "trata-se das religiões indígenas e de diversas expressões das religiões afro-americanas" (SANTA ANA, 1987, p. 11). O autor reconhece haver uma ausência de reflexão ecumênica com essas expressões religiosas e vaticina:

O movimento ecumênico na América Latina é seriamente desafiado a levar estas religiões em conta no seu diálogo comum. Isto é, considerá-las seriamente, o que significa não as desacreditar rapidamente como se fossem formas "primitivas" de algum tipo de "superstição" (SANTA ANA, 1987, p. 11).

O movimento ecumênico não abraçou esse desafio de maneira sistemática e propositiva. Talvez o relacionamento do protestantismo com as tradições religiosas originárias tivesse sido outro, com maior inserção cultural no continente. Mesmo não tratando do tema das religiões, Júlio de Santa Ana (1987, p. 301) termina a sua obra chamando a atenção, mais uma vez, para que o movimento ecumênico dê a sua contribuição na elaboração de uma teologia que trate com respeito e igualdade as demais expressões religiosas no continente: "O movimento ecumênico na América Latina só alcançará sua maturidade quando entrar em diálogo sério, em pé de igualdade (por conseguinte, descendo do cavalo do branco conquistador e arrogante), com as formas religiosas ainda existentes dessas culturas". Talvez esteja aí uma das dificuldades que a teologia protestante latino-americana tem em formular reflexões teológicas que dialoguem com a diversidade dos povos e, concomitantemente, com a pluralidade religiosa.

Outro autor de destaque no movimento ecumênico latino-americano, Zwínglio M. Dias, de tradição presbiteriana, alertou para a necessidade de ampliar o debate ecumênico com as demais expressões religiosas presentes na América Latina. O protestantismo latino-americano de tendência ecumênico-progressista buscou a unidade com as demais igrejas e um relacionamento fraterno com a Igreja Católica, mas não se debruçou 
com profundidade para observar as demais expressões religiosas e refletir teologicamente a partir do lugar dessas religiões, é o que constata, igualmente a Santa Ana. Ainda que não seja tarde para pensar nas possibilidades teológicas e dialógicas com as demais expressões religiosas no continente, Dias (2009, p. 130) assegura: "Para esse projeto de unidade, impõe-se também uma atitude de abertura e receptividade fraterna frente às demais religiões não-cristãs". Dentro dessa perspectiva de unidade (diálogo inter-religioso), o autor reconhece algo que vem se repetindo constantemente com as demais expressões religiosas, qual seja, as religiões não-cristãs "vêm sendo sistemática e continuadamente desqualificadas, reprimidas, retomadas e desprezadas, quando não totalmente erradicadas, em nome da fé cristã" (DIAS, 2009, p. 130). Essa postura beligerante de grande parte do protestantismo que se inseriu na América Latina deixou como herança uma teologia agressiva quando diante de outras expressões religiosas. As consequências dessa teologia estão evidentes na teologia de missão que ainda opera com pressupostos coloniais, imprimindo um "deus" ocidentalizado nas relações missionárias, principalmente quando em contato com povos indígenas, mas também massacrando político-ideologicamente as religiões de matriz africana, tendo a intolerância como um fator, infelizmente, corriqueiro. Por essa razão, Dias (2009, p. 130) admite: "Falar em diálogo a partir do locus do cristianismo ainda soa ameaçador e perigoso para muitas formas de religiosidade". Ameaçador e perigoso por se colocar como o detentor de uma verdade a-histórica e transcendente, capaz de menosprezar culturas e tradições religiosas por não estarem dentro de uma concepção anglo-saxã de "cristianismo". ${ }^{4}$ É a partir desse quadro que procuramos contribuir, ou seja, propor uma teologia das religiões que dialogue com as demais expressões religiosas, considerando suas premissas culturais e teológicas. Com isso, aceitamos o desafio de pensar uma teologia das religiões que proponha uma narrativa teológica que coadune com as culturas autóctones e ajude a diminuir a incidência de posturas teológicas marcadas pela prepotência de serem a "única" alternativa. De acordo com Dias (2009, p. 130), o protestantismo ecumênico-progressista

\footnotetext{
4 "Os missionários sempre foram representantes de uma cultura diferente, e seria impossível que, ao pregar o evangelho, eles não pregassem também, ainda que não o desejassem, os seus valores culturais. É curioso observar como o Cristo da arte protestante é um tipo que exibe certos traços raciais e de estilo peculiares aos anglo-saxões. O mesmo aconteceu com a pregação: o evangelho foi transmitido sob uma forma cultural que não lhe pertencia, e mais do que isto, que era estranha àqueles a quem era pregado. Assim, frequentemente, converter-se a Cristo significava alienar-se da cultura mãe" (ALVES, 1982, p. 64).
} 
na América Latina ainda está dando os primeiros passos para iniciar uma reflexão que trate "de olhar com simpatia, atenção, fraternidade e reverência para as religiões populares de nosso continente, como são as expressões da religiosidade indígena e as manifestações dos ritos afro-americanos". É premente elaborar reflexões teológicas que procurem dialogar com as expressões religiosas latino-americanas. A ausência de uma reflexão assim contribuiu (e ainda contribui) para que outras narrativas teológicas, não tão condescendentes com essas expressões religiosas, florescessem no continente, sendo mediadoras de um neocolonialismo que mantém o mesmo modus operandi das primeiras colonizações. Refletir teologicamente e dialogar com essas expressões religiosas pode nos ajudar "a ir mais longe do que fomos até agora em nossa aventura ecumênica" (DIAS, 2009, p. 130). Entendemos que não apenas chegou o momento, como também estamos atrasados quanto ao tempo histórico, principalmente quando forças político-ideológicas, no caso do Brasil, se apropriaram do discurso religioso para silenciar e vilipendiar povos indígenas, bem como minorias.

A partir desse quadro, entendemos que reflexões que contemplem essa demanda são bem-vindas quando contribuem para uma reflexão teológica engajada e propositiva. Tendo isso como ponto de partida, acolhemos as reflexões teológicas de Alessandro Rodrigues Rocha e Claudio de Oliveira Ribeiro. Alessandro dedicou-se ao estudo da Teologia Fundamental durante a sua carreira acadêmica. Falecido em janeiro de 2019, o autor se ocupou em repensar a teologia para além do discurso da univocidade teológica que tem na metafísica a sua matriz de reflexão e divulgação. Claudio de Oliveira Ribeiro vem se destacando como um dos poucos teólogos de tradição protestante a pensar sobre uma teologia das religiões a partir do que ele denomina como princípio pluralista. Ambos, além de amigos e parceiros em publicações, ${ }^{5}$ pautam suas reflexões teológicas na condição plural da sociedade, dando o devido destaque à tradição protestante em diálogo com temas relevantes.

\section{O princípio pluralista como chave de leitura da realidade latino- -americana}

Claudio de Oliveira Ribeiro tem procurado tratar a teologia protestante latino-americana em consonância com as expressões religiosas, tendo o

Alessandro Rocha e Claudio de Oliveira Ribeiro organizaram o livro Ecumenismo e reforma (2017). Além desse importante texto em comemoração aos 500 anos da Reforma protestante, os autores escreveram, juntamente com o autor desse artigo, o livro $A$ outra porta da igreja (2015). 
pluralismo religioso como princípio. Com isso, ele propõe algumas bases para o diálogo inter-religioso tendo como trilha o caminho aberto pelo movimento ecumênico.

Ao articular uma teologia protestante ecumênica das religiões com incidência nos problemas e principais questões da América Latina, Ribeiro (2017, p. 11-12) desenvolveu uma mediação hermenêutica para observar a realidade, trata-se do princípio pluralista. É um modo que

possibilita divergências e convergências novas, outros pontos de vista, perspectivas críticas e autocríticas para diálogo, empoderamento de grupos e de visões subalternas e formas de alteridade e de inclusão, considerados e explicitados os diferenciais de poder presentes na sociedade.

O princípio pluralista é fruto de uma composição interdisciplinar, tecido a partir de diferentes esquemas epistemológicos, sejam eles oriundos dos estudos culturais (Homi Bhabha), teológicos (Paul Tillich) ou sociológicos (Boaventura de Souza Santos). A partir disso, Ribeiro (2017, p. 12) tem no princípio pluralista a possibilidade de "melhor compreensão da diversidade do quadro religioso e também das ações humanas [...] Com ele, as análises tornam-se mais consistentes, uma vez que possibilitam melhor identificação do "outro"'. Tendo como lógica a dimensão ecumênica, Ribeiro (2017, p. 14-15) tem no princípio pluralista uma forma de enxergar as ambiguidades da realidade religiosa que não obedecem a uma regra fixada ou a um código doutrinário restrito. Antes, o princípio pluralista é capaz de dar visibilidade para, por exemplo, ler o "número significativo de pentecostais e batistas que atuam em áreas periféricas como favelas e ocupações rurais e urbanas, comunidades evangélicas inclusivas que integram pessoas homoafetivas na dinâmica eclesial, incluindo o ministério pastoral". O princípio pluralista é um modo de enxergar e entender que, mesmo com ambiguidades, a realidade religiosa não se torna binária, mas, sim, marcada pela multiplicidade e arranjos que, por vezes, fogem ao escopo de análises monolíticas. Assim, há um ecumenismo de cúpula, confessional e eclesiástico, mas também, a partir do princípio pluralista, é possível um ecumenismo que ultrapassa "estas iniciativas mais doutrinais, construindo-se como outro espaço de variadas expressões de espiritualidade e de incidência pública, não tão relacionado às práticas institucionais, mas às ações pessoais e comunitárias" (RIBEIRO, 2017, p. 16). Concebendo a realidade cultural, social e religiosa a partir do princípio pluralista, não caberiam posturas dogmáticas e enrijecidas, e, ainda que haja o mesmo espaço para que discursos e práticas assim ocorram, essas posturas estariam deslocadas da realidade patentemente plural. É por isso que Ribeiro 
(2017, p 18) ressalta: “Consideramos que a visão pluralista supera outros modelos da teologia ecumênica cristã como aquele que considera Jesus Cristo e a Igreja como caminho exclusivo de salvação".

Com a perspectiva do princípio pluralista, Ribeiro (2014, p. 16) entende que "os elementos-chaves da vivência religiosa e humana em geral são alteridade, respeito à diferença e o diálogo e a cooperação prática e ética em torno da busca da justiça e do bem comum". Em diálogo com autores católicos e protestantes, o autor demarca os campos de atuação da teologia das religiões, demonstrando a sua atualidade diante dos desafios latino-americanos e contribuindo para que o diálogo inter-religioso tenha fôlego entre as experiências religiosas marcadas pela pluralidade. Ribeiro está atento aos limites que a teologia latino-americana tem em relação à temática das religiões. Assim, sabe-se que a teologia latino-americana da libertação, ainda que atuante em setores populares, não atentou para a pluralidade cultural-religiosa no continente. Antes, "a teologia latino-americana priorizou o dado político para suas interpretações e nem sempre esteve atenta às diferenças culturais" (RIBEIRO, 2017, p. 8). Nesse sentido, o princípio pluralista contribui para que uma leitura teológica seja viabilizada a partir das realidades prementes do continente latino-americano. A partir de um profundo comprometimento com a alteridade, ou seja, o outro tem igual dignidade e valor intrínseco e, por outro lado, tendo as pegadas do movimento ecumênico como base para a construção de uma teologia ecumênica das religiões, é possível "reforçar as experiências religiosas que se constituem como aprofundamento dos processos de humanização, da democracia, da cidadania e da capacidade contra-hegemônica na defesa de direitos humanos e da terra" (RIBEIRO, 2017, p. 12). A percepção quanto à pluralidade e seus desafios contribui quando da formulação teológica que trata das dimensões humanas em seus aspectos objetivos, concretos, o chão da vida, como também subjetivos, das identidades e utopias.

Uma vez lidando com o contexto religioso latino-americano, mais detidamente o brasileiro, com sua hibridização e pluralidade inerente, o princípio pluralista se apresenta como uma importante chave de leitura da realidade social, mas principalmente religiosa. Com isso, ainda que haja espaço para idiossincrasias e fundamentalismos marcados por intolerância, em muitos casos, criminosa, é plausível a percepção de que, a partir do princípio pluralista, a reflexão teológica e o diálogo inter-religioso estão para além dos enrijecimentos dogmáticos, ultrapassando questões meramente doutrinárias, tecendo espaços de espiritualidade e presença pública e não tendo, necessariamente, relação com modelos eclesiásticos ou políticas 
denominacionais, mas sim com iniciativas ecumênicas e dialogais entre pessoas e comunidades religiosas (RIBEIRO, 2017, p. 16).

\section{Teologia protestante: a emergência de uma epistemologia teoló- gica que seja plural}

Claudio de Oliveira Ribeiro tem se ocupado em tratar o princípio pluralista como principal chave de leitura para a realidade latino-americana, não apenas religiosa, mas cultural e social. A sua produção não vem tratando do aspecto teológico como construção epistemológica para um pensar sistemático quanto à teologia latino-americana. Como um representante da teologia latino-americana da libertação no campo protestante, Ribeiro já apontou algumas críticas quanto ao modelo teológico gestado pela teologia latino-americana, ${ }^{6}$ mas não se ocupou, até o momento, em fornecer uma análise quanto à epistemologia teológica no sentido de apontar as dificuldades do discurso teológico considerado hegemônico no protestantismo latino-americano. Isso poderia ter uma razão, uma vez que o autor esteja, já há alguns anos, comprometido com a teologia latino-americana da libertação e as dificuldades do campo teológico protestante, de majoritária presença de autores fundamentalistas, não seja a sua preocupação de produção teológica. Quem faz esse caminho é Alessandro Rodrigues Rocha. Este autor está mais inclinado ao segmento teológico conhecido como teologia da missão integral ${ }^{7}$ e, por essa razão, mais inteirado dos problemas e dificuldades que o discurso teológico de cunho mais conservador abriga. Como professor de teologia em diferentes seminários e faculdades teológicas, Rocha se preocupou com o discurso teológico, ou seja, a base epistemológica do discurso teológico que dá sustentação doutrinária e, por vezes, fundamentalista, para posturas enrijecidas pela doutrina, algo com o que lidou ao longo da carreira docente.

6 O autor concentrou suas considerações no texto RIBEIRO, Claudio de Oliveira. Testemunho e libertação: a teologia latino-americana em questão. São Paulo: Fonte Editorial, 2016. Atento aos novos desafios da contemporaneidade, o autor trabalha com alguns pressupostos: a complexidade da realidade socioeconômica e religiosa; as formas de espiritualidade; o pluralismo religioso. Esses são os principais pressupostos para o diálogo com a teologia latino-americana que o autor procura fazer e, como consequência, tecer algumas críticas quanto às deficiências do método teológico.

7 O autor, em parceria, escreveu uma síntese teológica sobre a teologia da missão integral, ver: ROCHA, Alessandro Rodrigues; VASCONCELLOS, Márcio Simão de. O poder da palavra na força do Espírito: elementos da fé cristã na perspectiva da teologia da missão integral. São Paulo: Garimpo, 2016. 
A premissa de Rocha se dá na constatação de que a teologia ocidental, portanto dogmática e sistemática (no contexto protestante) opera a partir de um discurso unívoco, ${ }^{8}$ que tem na metafísica a base para a sua epistemologia. Na base epistemológica desta teologia está a filosofia grega que, "distanciando-se da polissemia geradora de plurivocidade, encontra na metafísica um instrumento adequado capaz de sustentar um discurso unívoco. Por ser unívoco ele pode ser dito como universal" (ROCHA, 2017, p. 14). O autor se dedica a fazer todo o caminho da filosofia grega quando da discussão entre os pré-socráticos, como Parmênides e Heráclito, em relação à verdade. Quando se chega à metafísica consolidada por Platão e Aristóteles, "a verdade alcançada pela filosofia a partir da metafísica é absoluta, porque se identifica com o ser (fundamento último da existência)" (ROCHA, 2017, p. 14). Como sabemos, a filosofia grega irá exercer uma indelével influência na teologia a partir dos pais da Igreja, mas de maneira sistemática a partir de Agostinho e Tomás de Aquino. Assim, "a teologia cristã encontra na filosofia grega o instrumental teórico capaz de lhe permitir comunicar sua experiência de fé" (ROCHA, 2017, p. 27). Com isso, a teologia tem, a partir de então, na metafísica e na lógica o seu instrumental unívoco de discurso teológico, no qual a metáfora é marginalizada e a metafísica toma o lugar de excelência para a produção teológica a partir de uma percepção de fechamento do discurso. A teologia, portanto, passa a "falar do ser, das ideias perfeitas, em suma, da verdade" (ROCHA, 2017, p. 28). Dentro dessa percepção, o discurso teológico na sua univocidade transcende as realidades culturais, porque detém as fórmulas corretas e o saber necessário. Com isso, nega-se toda a forma de pluralidade e se estabelece como o ordenamento maior e impreterível (ROCHA, 2017, p. 40). As raízes dessa teologia, gerida a partir da metafísica, têm como fim se impor de cima para baixo, não cabendo perguntas, porque as respostas já foram todas dadas (ROCHA, 2017, p. 41). Participam dessa construção teológica não apenas a dogmática católica, mas também o protestantismo. O protestantismo, a partir da ortodoxia, se especializou em "manuais de caráter totalizadores do conjunto dos temas da fé e de tendência universalizante" (ROCHA, 2017, p. 43). Como romper com

\footnotetext{
"Abordagem que advoga a continuidade entre o discurso e a realidade. Identificação de um discurso com o real, de forma que qualquer outra tentativa de nomear esse real seja imediatamente tida como falsa. A univocidade sustenta sua condição de exclusividade discursiva" (ROCHA, 2007, p. 179-180).
} 
esse discurso? Abordando o discurso teológico a partir da equivocidade. ${ }^{9}$ Isso se dá com o rompimento de mecanismos de controle do discurso teológico (ROCHA, 2007, p. 106). O discurso teológico hegemônico em vigor, marcado pela sua epistemologia fundada na metafísica e detentor de um saber unívoco, com clara pretensão universalizante, está pautado pelos manuais de teologia em que o principal personagem não é Javé, o Abbá de Jesus de Nazaré, mas sim o Theos da filosofia grega. As principais questões que envolvem Theos são onisciência, onipotência e onipresença. Romper com esse discurso teológico unívoco é possível quando há uma percepção do lugar de fala, ou seja, o locus hermenêutico.

Pode parecer uma obviedade, mas ainda é algo que necessita ser reafirmado: "O discurso humano sobre qualquer realidade, mesmo a divina, deverá assumir sua irredutível condição existencial. Nenhuma fala pode pretender uma identificação com a realidade que não seja aquela que circunda quem a propõe" (ROCHA, 2007, p. 130). O lugar de fala envolve a condição existencial e cultural de quem pronuncia o discurso, portanto, o discurso é sempre equívoco e não unívoco. O nosso autor, quando assim se expressa, está ancorado em importantes nomes que fizeram o devido rompimento com o pensamento metafísico, entre eles está Nietzsche e como principal intérprete do filósofo alemão, o filósofo italiano Gianni Vattimo. A partir disso, o autor acentua a condição da pluralidade do cristianismo e da teologia, recuperando, portanto, o lugar de fala do outro e assim "o múltiplo, o plural, é a outra fala, a fala do outro, que tem tanta relevância para sua comunidade religiosa e cultural quanto a fala do eu tem para a sua" (ROCHA, 2007, p. 135). O reconhecimento do lugar de fala do outro é condição sine qua non para o rompimento de um pretenso discurso teológico pautado pela univocidade. "A adesão às pequenas narrativas como forma de rejeição a discursos totalizadores coloca o pensamento e a tarefa de produção de conhecimento diante da irredutível condição plural" (ROCHA, 2017, p. 97).

\section{Na esteira de uma teologia protestante das religiões}

Uma teologia das religiões em perspectiva protestante que tenha incidência na América Latina precisa repensar a concepção de revelação. Propor

\footnotetext{
9 “A expressão equivocidade evoca o termo equívoco [...] Tomamos a expressão aqui não em seu sentido de dicionário, em que equívoco é sinônimo de erro, mas na perspectiva da filosofia da linguagem, na qual equívoco está em contraposição direta a unívoco. A condição da linguagem em que um nome pode evocar várias interpretações, sem estar subordinado a um conceito fechado" (ROCHA, 2007, p. 173-174).
} 
o debate em torno de um dos temas mais caros para a teologia cristã é um desafio, mas é necessário assumi-lo. Isso se deve porque há uma postura de encerramento da revelação no cristianismo, mesmo considerando as demais tradições religiosas como mediadoras do sagrado. Entre os teólogos católicos, há um intenso debate a partir da singularidade do cristianismo, considerando-lhe como o fechamento unívoco da revelação. O contrário dessa concepção em relação à salvação é passível de processos envolvendo a Congregação para a Doutrina da Fé. No caso do protestantismo, por razões de pluralidade e por não ter um centro normatizador da doutrina, esse processo tende a ser mais facilitado, qual seja, repensar a revelação a partir de uma teologia das religiões.

Ao nosso ver, é preciso fazer uma reflexão em torno da revelação porque há uma perceptível colonização do aspecto revelacional operando na formulação do discurso teológico com notória consequência na tarefa missionária, principalmente entre povos indígenas. O discurso teológico que alimenta a missão é carregado por uma noção de revelação unívoca, não cabendo qualquer espaço para a pluralidade. Assim, na revelação que forja a tarefa missionária entre os indígenas, o discurso teológico é unívoco, vertical e monoteísta. O Jesus de Nazaré, expressão do amor de Javé, tendo casa, geografia, língua e cronologia, é tido como o metafísico Ser revelador do poder de "Deus" (Theos). A tarefa missionária se faz a partir dele, por entender que ele é universal, no sentido de ser preexistente. Essa teologia (cristologia salvacionista) é patente na construção teológica missionária: "É necessário comunicar a mensagem de um Jesus universal preexistente, justamente porque não damos por certo que todos estejam captando corretamente a revelação" (OLIVEIRA, 2017, p. 121). O autor frisa que a necessidade de comunicar a mensagem de Jesus (sendo este universal e preexistente) se dá porque não se está convencido de que a revelação está sendo captada corretamente. Nesse sentido, o autor ainda mantém as mesmas premissas da teologia colonial, quais sejam: é preciso levar a mensagem correta; esses povos (no caso dos Quéchuas, por se tratar de David M. de Oliveira) ainda não possuem as condições necessárias para captar corretamente a revelação de Deus. Como se faz isso? Por meio da inculturação da fé (OLIVEIRA, 2017, p. 121). Ainda que o autor admita que isso "não quer dizer que antes dos missionários a salvação de Jesus não lhes podia alcançar", reitera que a revelação "se dá de modo pleno em Jesus. Por isso é preciso conhecê-lo" (OLIVEIRA, 2017, p. 121). O discurso teológico está tão imbricado com a presunção da revelação de maneira universal em Jesus Cristo que não é possível nem mesmo atentar para as configurações da própria percepção da 
revelação que o cristianismo tem, assim como as demais religiões. Ainda que os critérios para se pensar no diálogo inter-religioso estejam sendo debatidos, há um certo acordo em torno de algumas questões que envolvem a revelação no cristianismo como também nas demais religiões. Ocorre que a leitura teológica estruturada a partir do Ocidente - influenciada pela filosofia grega, por isso se trata de $\underline{\Theta \varepsilon o ́} \varsigma$ - não atenta, num primeiro momento, para o fato de que as demais religiões, na falta de uma outra nomenclatura, possuem teologia, portanto nutrem nas suas expressões religiosas a percepção da revelação: "Uma vez que temos diferentes teologias que emanam de diferentes povos e culturas, podemos esperar diferenças na forma em que as revelações divinas são expressas" (BALASURIYA, 2006, p. 26). Essa constatação precisa estar sendo contemplada em teologias descoloniais, do contrário será a reprodução do mesmo modus operandi de teologias enrijecidas e desconectadas da realidade cultural e social de uma gente. Antes, é preciso reafirmar: "Não há revelação universal por cima de culturas vivas. A revelação cristã não foge à regra" (SUSIN, 1991, p. 188). Ainda assim, parece ser possível constatar que em algumas leituras teológicas, o cristianismo não participa, assim como as demais religiões, da mesma condição histórica no que se refere à revelação. Assim como outras religiões com os seus códigos, o cristianismo "é uma revelação acontecida numa cultura específica, com cânones próprios, que só podem ser detectados nos traços culturais de Israel e mais especificamente de Jesus de Nazaré" (SUSIN, 1991, p. 188). O discurso universalizante de uma teologia monolítica não cabe em um contexto onde a pluralidade não é apenas um fato, mas um desafio ao diálogo.

A missão entre os indígenas precisa ser reconsiderada em suas dimensões culturais, teológicas e político-sociais. Quanto à experiência religiosa dos povos indígenas, elas têm muito a ensinar o cristianismo ocidentalizado que separou a vida social, política e religiosa, compartimentando todas elas em lugares específicos, não se encontrando nas demandas da vida em sociedade. Se, antes, a evangelização funcionou como meio civilizatório entre esses povos, ao que parece o trabalho missionário se inverteu. São os indígenas, com sua teologia da terra e do bem viver, que precisam evangelizar, a começar pelo "conceito" de Deus, que a cultura ocidentalizada forjou numa imagem de "Deus Todo-poderoso", desprovido de comunhão e pluralidade.

Um desafio implícito que os povos indígenas apresentam às culturas ocidentais cristãs de origem europeia é a revisão do conceito de Deus como Senhor. Deus não é aquele que manda, como os senhores que conhecemos, mas é aquele que acompanha o seu povo oprimido no caminho da superação de suas mazelas (TREIN, 2015, p. 36). 
Essa imagem de um "Deus-colonizador" precisa começar a ser superada a partir de uma linguagem teológica sobre Deus que assegure a sua pluralidade, diversidade, demonstrando, assim, que o Deus uno-trino agrega essas dimensões quando concebido como trindade, ou seja, a coexistência é comunitária e o monoteísmo estrito não se coaduna com a natureza trinitária. Em relação aos povos originários e suas expressões religiosas, é importante acentuar a condição primeira de percepção do sagrado e suas manifestações na cultura, nos ritos e na própria teologia. Leonardo Boff (1990, p. 80) ficou conhecido por popularizar uma máxima: "O Deus-Trindade chega sempre antes que o missionário". Essa compreensão teológica do Deus uno-trino como o primeiro missionário ainda preserva uma concepção teológica colonial, principalmente quando se postula que "o primeiro missionário e evangelizador é o próprio Deus-Trindade” (BOFF, 1990, p. 80). A questão está nessa compreensão, ou seja, de que o Deus cristão sempre chega primeiro, isto é, ele já está lá, mas ainda não foi "descoberto" pelos ameríndios.

\section{Considerações finais}

Ainda que nossos autores aqui analisados, Ribeiro e Rocha, contribuam para a reflexão teológica engajada com a realidade latino-americana, propondo uma discussão teológica que atenta para a pluralidade religiosa; ambos não tratam da revelação como questão fulcral para se pensar uma teologia protestante das religiões. Esse caminho ainda está por ser feito na teologia protestante latino-americana. Ribeiro está atento aos desafios da América Latina e comprometido com o diálogo inter-religioso a partir da dimensão ecumênica. A contribuição de Ribeiro se dá na percepção plural da realidade, tornando a pluralidade um princípio, ou seja, a pluralidade é indissociável da realidade, não sendo, portanto, possível ignorar esse fato quando em análises teológicas em diálogo com os temas latino-americanos. Rocha, por outro lado, nos ajuda a romper com o discurso totalizante e unívoco que marca a reflexão teológica protestante na América Latina, ainda muito dependente da forma de pensar herdada do mundo anglo-saxão. Tanto Ribeiro quanto Rocha marcam um momento importante na reflexão teológica latino-americana. Ambos edificam suas questões teológicas a partir da tradição protestante, portanto, espíritos livres (ainda que em tese) de documentos regulatórios e de uma teologia unívoca que se pretende hegemônica. Ambos rompem com um discurso teológico unificador e colonial, dando vazão à pluralidade em sua concepção mais colorida possível. 


\section{Referências bibliográficas}

ALTMANN, Walter. O pluralismo religioso como desafio ao ecumenismo na América Latina. In: SUSIN, Luiz Carlos (Org.). Sarça ardente: teologia na América Latina prospectivas. São Paulo: Paulinas; SOTER, 2000, p. 391-414.

ALVES, Rubem. Dogmatismo e tolerância. São Paulo: Paulinas, 1982.

BALASURIYA, Tissa. Revelação e revelações. In: TOMITA, Luiza E.; VIGIL, José M.; BARROS, Marcelo (Orgs.). Teologia latino-americana pluralista da libertação. São Paulo: Paulinas, 2006, p. 19-44.

BITTENCOURT FILHO, José. Pluralismo religioso: um desafio ao ecumenismo. In: Koinonia (Org.). O sonho ecumênico: prefácio ao novo milênio. Rio de Janeiro: Koinonia, 1995 , p. 45-47.

BOFF, Leonardo. Nova evangelização: perspectiva dos oprimidos. 2. ed. Petrópolis: Vozes, 1990.

DIAS, Zwinglio M. Alguns marcos decisivos na trajetória do movimento ecumênico na América Latina e no Caribe. In: SINNER, Rudolf von (Org.). Missão e ecumenismo na América Latina. São Leopoldo: Sinodal, 2009, p. 117-130.

LONGUINI NETO, Luiz. O novo rosto da missão: os movimentos ecumênico e evangelical no protestantismo latino-americano. Viçosa: Ultimato, 2002.

OLIVEIRA, David Mesquiati de. Diálogo e missão nos Andes: um estudo de teologia da missão latino-americana. São Paulo: Reflexão, 2017.

RIBEIRO, Claudio de Oliveira. O princípio pluralista. Cadernos Teologia Pública, São Leopoldo, Ano XIV, v. 14, n. 128, 2017.

RIBEIRO, Claudio de Oliveira. Pluralismo e libertação. São Paulo: Paulinas, 2014.

RIBEIRO, Claudio de Oliveira. Testemunho e libertação: a teologia latino-americana em questão. São Paulo: Fonte Editorial, 2016.

RIBEIRO, Claudio de Oliveira; ROCHA, Alessandro Rodrigues (Orgs.). Ecumenismo e reforma. São Paulo: Paulinas, 2017.

ROCHA, Alessandro Rodrigues. Modos de crer e conhecer: relações entre teologia e epistemologia. Rio de Janeiro: Letra Capital, 2017.

ROCHA, Alessandro Rodrigues. Teologia sistemática no horizonte pós-moderno: um novo lugar para a linguagem teológica. São Paulo: Vida, 2007.

ROCHA, Alessandro Rodrigues; GONÇALVES, Alonso de Souza; RIBEIRO, Claudio de Oliveira. A outra porta da igreja: eclesiologias contemporâneas em foco. São Paulo: Reflexão, 2015.

ROCHA, Alessandro Rodrigues; VASCONCELLOS, Márcio Simão de. O poder da palavra na força do Espírito: elementos da fé cristã na perspectiva da teologia da missão integral. São Paulo: Garimpo, 2016. 
SANTA ANA, Júlio de. Ecumenismo e libertação: reflexões sobre a relação entre a unidade cristã e o reino de Deus. Petrópolis: Vozes, 1987.

SUSIN, Luiz Carlos. Revelação e condicionamento cultural. In: SUESS, Paulo (Org.). Culturas e evangelização: a unidade da razão evangélica na multiplicidade de suas vozes - pressupostos, desafios e compromissos. São Paulo: Loyola, 1991, p. 173-189.

TREIN, Hans Alfred. Religiões indígenas desafiam reflexões bíblico-teológicas sobre Deus, criação e terra. In: ZWETSCH, Roberto E. (Org.). Conviver: ensaios para uma teologia intercultural latino-americana. São Leopoldo: Sinodal, 2015, p. 31-44.

WIRTH, Lauri Emílio. Contribuições do campo protestante para o estudo das religiões. In: MANOEL, Ivan A.; FREITAS, Nainora M. B. (Orgs.). História das religiões: desafios, problemas e avanços teóricos, metodológicos e historiográficos. São Paulo: Paulinas, 2006, p. 83-94.

Submetido em: 18-8-2019

Aceito em: 25-10-2019 